Biogeosciences Discuss., https://doi.org/10.5194/bg-2017-511

Manuscript under review for journal Biogeosciences

Discussion started: 11 January 2018

(c) Author(s) 2018. CC BY 4.0 License.

\title{
Plants in movement - Floristic and climatic characterization of the New Jersey hinterland during the Palaeogene-Neogene transition in relation to major glaciation events
}

Sabine Prader ${ }^{1,2}$, , Ulrich Kotthoff ${ }^{1,2}$, Francine M.G. McCarthy ${ }^{3}$, Gerhard Schmiedl ${ }^{4,2}$,

5 Timme H. Donders ${ }^{5}$ and David R. Greenwood ${ }^{6}$

1 Center for Natural History, Hamburg University, Bundesstraße 55, D-20146 Hamburg, Germany

2Institute of Geology, University of Hamburg, Bundesstrasse 55, D-20146 Hamburg, Germany

3Department of Earth Sciences, Brock University, 1812 Sir Isaac Brock Way, St. Catharines, Ontario, L2S 3A1, Canada

4Center for Earth System Research and Sustainability, Hamburg University, Bundesstraße 55, D-20146 Hamburg, Germany

5Palaeoecology, Department of Physical Geography, Heidelberglaan 23584 CS Utrecht, The Netherlands

6Department of Biology, Brandon University, 270 18th Street, Brandon, Manitoba, R7A 6A9, Canada

Correspondence to: Sabine Prader (sabine.prader@uni-hamburg.de)

Abstract. Mid-Oligocene to Early Miocene terrestrial palynomorphs from the New Jersey hinterland (eastern North America: IODP-Expedition 313) were analysed, using light microscopy and scanning electron microscopy, to infer altitudinal spatial

15 and long-term temporal vegetation migration in context of global climate change. The mesophytic forest was the most widespread vegetation type in the hinterland, with Quercus (Group Quercus, Quercus/ Lobatae and aff. Group Protobalanus) being the dominant taxon. Pollen grains of the extinct genus Eotrigonobalanus (Fagaceae) are documented.

To infer possible topographic palaeovegetation movements during the selected time interval terrestrial palynomorphs were assigned to six vegetation units. Relative abundances of vegetation units show weak temporal and spatial fluctuations, with the sum of bisaccate pollen grains being most pronounced. Periodic changes in vegetation units suggest movements of the plant cover responding to orbital-scale glacial-interglacial changes of the Oligocene and early Miocene. Relative abundances of several taxa (e.g. Carya) did not change significantly during the Oligocene, but alterations are recognizable when compared with an already published late Middle Miocene record from the same area, probably indicating biotic responds to environment change. A pollen-based bioclimatic analysis with four standard parameters (mean annual temperature, mean temperatures of the coldest and warmest month, mean annual precipitation) was performed to reconstruct palaeoclimatic changes indicating weak fluctuations in temperature and precipitation.

\section{Introduction}

At the Eocene-Oligocene boundary (EOB) at $\sim 33.7$ Ma global climate began to transform from a greenhouse to an icehouse state (Zachos, et al., 2001; Pagani et al., 2005; Eldrett et al., 2009). Various mechanisms are under debate as to what caused the large-scale glaciation of Antarctica around the first Oligocene isotopic event (Oi-1 event), including the opening of the Drake Passage (Scher and Martin, 2006), the decline of atmospheric carbon dioxide concentrations (Pagani et al., 2005), and 
Biogeosciences Discuss., https://doi.org/10.5194/bg-2017-511

Manuscript under review for journal Biogeosciences

Discussion started: 11 January 2018

(c) Author(s) 2018. CC BY 4.0 License.

orbital forcing (Coxall et al, 2005). The Oligocene is marked by a series of eight unipolar glaciation periods (Pekar et al., 2002), during which Antarctica experienced ice sheet growth, resulting in large glacioeustatic sea level fluctuations (Pekar et al., 2002; Wade and Pälike, 2004; Pälike et al., 2006; Pekar et al, 2006). Waxings and wanings of Eastern Antarctic ice sheets (EAIS; Zachos et al., 2001) during the Oligocene were not all of the same magnitude. The strongest glacial episode during this 5 epoch is represented by the Oi-2b event (27.0 Ma - 26.6 Ma; Pekar et al., 2006) (Pälike et al., 2006), which resulted in a glacioeustatic lowering of $\sim 45 \mathrm{~m}$ (Pekar et al., 2002). These climate oscillations are attributed to insolation changes associated with orbital forcing (Wade and Pälike 2004; Pälike et al., 2006).

The inception of the Miocene isotopic event 1 (Mi-1 event), the second largest climatic aberration since the Oi-1 event (Lear et al., 2004), coincides with the Oligocene-Miocene boundary (OMB) at $20.03 \mathrm{Ma}$ (Liebrand et al., 2011). It represents the

10 first and largest cooling episode during the Miocene with a sea-surface temperature decline of $\sim 2 \mathrm{C}^{\circ}$ occurring prior the event (Lear et al., 2004). Mechanisms behind this global cooling event are probably related to late Oligocene atmospheric carbon dioxide levels being near to those of modern times (Pagani et al., 2005; Roth-Nebelsick et al., 2014) and orbital forcing (Zachos et al., 2001; Pälike et al., 2006).

From a terrestrial perspective, the equator to pole climatic gradient became more pronounced since the Oi 1 global event,

15 resulting in a predominantly temperate climate in the mid latitudes of the Northern Hemisphere (Hably et al., 2000). This time interval was important for a renewal of the North American (Graham, 1999) and other floras (e.g. Eldrett et al., 2009). Most records of early Oligocene age from the mid latitudes of Europe indicate a prevailing deciduous vegetation character with intermixed Eocene floristic elements like Eotrigonobalanus (e.g. Velitzelos et al., 2014). Only a few early Oligocene records imply highly diverse broad-leaved macrofloristic assemblages in the mid latitudes (Kovar-Eder, 2016). Terrestrial records of the Southern Hemisphere indicate an increase of temperate tree taxa in the fossil record too, with Nothofagus being the dominant taxon (e.g. Prebble et al., 2017).

Most information about the floristic and climatic history of the Oligocene of North America is derived from western (e.g. Meyer and Manchester, 1997; Grímsson et al., 2016) and interior deposits (e.g. Wolfe and Schorn, 1989; 1990) of the continent. For the early Oligocene, records from the western part of North America document a dominance of temperate climates, promoting the growth of deciduous forests with a small portion of broadleaf evergreens in the understorey (Meyer and Manchester, 1997) and persistent single warmth-loving elements of the Eocene (Grímsson et al., 2016). At the same time, intensifying seasonality triggered the development of open landscapes and dry conifer woodlands in the interior of the country (Wolfe and Schorn, 1989; 1990). By the end of the Oligocene, the prevailing climate determined the formation of open grasslands in the western interior of North America (Retallack, 2004; Strömberg, 2005).

The palaeofloristic and terrestrial environment of eastern North America is not well understood due to a scarcity of fossil Oligocene floras (e.g. Frederiksen, 1991). Generally, terrestrial palynomorphs deposited in marine and continental sediments are well suited for the reconstruction of palaeoclimate (e.g. Eldrett et al., 2009), palaeovegetation (e.g. Kmenta and Zetter 2013) and biogeographic history (e.g. Grímsson et al., 2016). Sediment cores drilled in the framework of the Integrated Ocean Drilling Program (IODP) Expedition (Exp.) 313 to the New Jersey Shallow Shelf (NJSS) allowed for the reconstruction of 
Biogeosciences Discuss., https://doi.org/10.5194/bg-2017-511

Manuscript under review for journal Biogeosciences

Discussion started: 11 January 2018

(c) Author(s) 2018. CC BY 4.0 License.

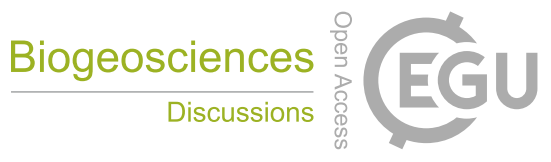

(c) (i)

Oligocene and Miocene terrestrial ecosystem development in eastern North America. The recovered deposits contain generally well preserved marine and terrestrial palynomorphs. Furthermore, a robust age model (Browning et al., 2013) was developed for these cores. Kotthoff et al. (2014) gave an overview of the OMB, including the related Mi-1 cooling event indicated by temperature decline and conifer expansion. However, only a few records world-wide (e.g. Prebble et al., 2017) deal with the

5 response of plant cover to Oligocene global climatic oscillations. Because global climate changes do not affect all regions at the same scale, biotic responses may differ from one environment to another (Utescher et al, 2015). Climate models indicate more constant conditions for the Atlantic east coast during the Oligocene than for other regions (von der Heydt and Dijkstra, 2006), implying a restricted vegetation turnover for the hinterland.

In these contexts, we have evaluated the regional floristic behaviour of the NJSS hinterland to provide a more detailed insight

10 into a mid-latitude terrestrial system during the middle Oligocene and the Early Miocene and thus to contribute to a better understanding of patterns of plant persistence/migration.

\section{Material and methods}

\subsection{Geological setting}

\subsubsection{Site M0027: selection, age model and core sediment description}

15 Our study focuses on sediments from Site M0027 recovered during IODP Expedition 313 to the New Jersey Shallow Shelf (NJJS). The drilling position of Hole M0027A is at $39^{\circ} 38.046^{\prime} \mathrm{N}$ and $73^{\circ} 37.301^{\prime} \mathrm{W}$ at $33.5 \mathrm{~m}$ water depth and at a site-shoreline distance of $40 \mathrm{~km}$ (Fig. 1). Site M0027 is the only of three recovered sites containing Oligocene sequences (Browning et al., 2013; Miller et al., 2013a, 2013b).

The age model is based on calcareous nannofossils, dinoflagellate cysts, planktic diatoms, Sr isotopes, and sequence stratigraphy (Browning et al., 2013; Miller et al., 2013a). The analysed core sediments comprise four sequences, which correlate with sea level high stands, while no sediments were deposited during sea-level lowstands (likely connected to glacial phases). Sequence O3 (617 to $538.68 \mathrm{mbsf}$ ), the oldest analysed sequence, was deposited between $\sim 29.3$ to $\sim 28.2$ Ma (late Rupelian/Chattian; Fig. 2). This sequence contains two intra-sequences, which are tied to facies changes: Sequence o.1 at 596.3 mbsf ( 29.0 Ma) and Sequence o.5 at $563.0 \mathrm{mbsf}$ ( 28.6 Ma; Miller et al., 2013a). Sequence O6 (538.68 to 509 or 515 mbsf, 25 see Supplement S1) comprises the uppermost part of the Oligocene and the transition to the early Miocene (Chattian/Aquitanian). The estimated age of sequence $\mathrm{O} 6$ is best dated to $\sim 23.5$ to $\sim 23.0 \mathrm{Ma}$. The early Miocene Sequence $\mathrm{m} 6$ (509 or 515 to $494.87 \mathrm{mbsf}$ ) covers an age interval of $\sim 20.9$ to $\sim 20.7 \mathrm{Ma}$ (Aquitanian). Sequence m5.8 (494.87 to 361.28) is dated to $\sim 20.1$ to $\sim 19.2 \mathrm{Ma}$ (late Aquitanian/early Burdigalian). For more details on age model compare Supplement S1. All analysed sequences lie within Lithological Unit VII, comprising coarse-grained to fine-grained sands interbedded with silty clay laminae (Expedition 313 Scientists, 2010). 
Biogeosciences Discuss., https://doi.org/10.5194/bg-2017-511

Manuscript under review for journal Biogeosciences

Discussion started: 11 January 2018

(c) Author(s) 2018. CC BY 4.0 License.

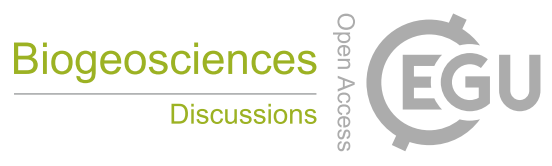

(c) (i)

Reconstructions by Scotese et al., (1988) imply that the NJSS study area was situated $\sim 2^{\circ}$ further south during the Oligocene and Miocene, and reached its modern position between $39^{\circ}$ and $40^{\circ} \mathrm{N}$ during the Pliocene. The onset of significant topography change and significant increase in relief variation of the Appalachian Mountains started at $\sim 20 \mathrm{Ma}$; prior to this time the Appalachians showed low modifications in relief and elevation (Liu, 2014).

$5 \quad 2.2$ Palynology

\subsubsection{Sample processing and analyses}

Sample processing was performed at Brock University, St. Catharines, Canada (sieving, $\mathrm{HCl}$ and HF-treatment) and at the Laboratory of University of Hamburg (acetolysis). Around 300-400 terrestrial palynomorphs were identified using mostly the acetolyzed treated material. For percentage calculations, bisaccate pollen grains were excluded from the reference sum as these

10 grains tend to be overrepresented in marine records (Mudie and McCarthy, 1994; Eldrett et al., 2009). Additionally, 300 marine/terrestrial palynomorphs were counted using the non-acetolyzed material due to sensitivity of some dinoflagellate cysts to acetolysis. The P:D ratio (pollen versus dinoflagellate cyst) is an indicator for transport mechanisms and sea-level fluctuations (McCarthy et al., 2003), where high P:D indicates low sea level and/or enhanced run off. In sum, 56 samples were analysed spanning the time interval of the middle late Oligocene to the early Miocene. Additionally, some pollen grains were

15 analyzed via SEM. We applied the Shannon-Wiener-Index $(\mathrm{H}(\mathrm{s}))$ in order to assess changes in diversity. More details on sample processing and analyses are given in Supplement S2.

\subsection{Reconstruction of palaeovegetation and palaeoclimate}

Terrestrial palynomorphs were grouped into six artificial palaeovegetation units: 1 : high-altitude conifer forest; 2 : mid-altitude conifer forest; 3: Cupressaceae; 4: mesophytic forest growing on well-drained soils; 5: mesophytic forest growing on moist/wet soils; 6: Mesophytic understorey; 7: plant community associated to coastal environments, growing on sun-exposed sandbanks. Grouping was done according to growing preferences of modern analogues, including soil condition and altitudinal zonation (Supplement S3). This superordinate artificial grouping is congruent with the vegetation units of the late Mid-Miocene of the same area (Prader et al., 2017). The generalisation allows inference of shifts within the terrestrial vegetation.

Reconstructions of palaeoclimatic conditions used the bioclimatic analysis after Greenwood et al. (2005) and Prebble et al.

25 (2017), which is based on the nearest living relative concept (NLR). Differences to the likewise NLR-based Coexistence Approach (Utescher et al., 2014) are described in detail in Prebble et al. (2017).

Four different climatic parameters were generated as a standard to characterize the palaeomacroclimatic conditions: mean annual temperature (MAT), coldest month mean temperature (CMMT), warmest month mean temperature (WMMT), and mean annual precipitation (MAP). The generated palaeoclimatic estimates were based on climatic profiles of North American and Chinese species (for details see Supplement S3). Table S3 summarizes the NLRs together with the climate source used. 
Biogeosciences Discuss., https://doi.org/10.5194/bg-2017-511

Manuscript under review for journal Biogeosciences

Discussion started: 11 January 2018

(c) Author(s) 2018. CC BY 4.0 License.

\section{Results}

\subsection{Terrestrial palynomorphs}

Fair preservation of pollen grains allowed for identification of 72 taxa. Supplement S3 gives a summary of all identified terrestrial palynomorphs. Light Micrograph (LM) images of several well-preserved plant microfossils are shown on Plates S4-

5 i and S4-ii (Supplement S4), and Plate I illustrates SEM images of selected pollen grains. Within the 56 analysed samples, Quercus is the most abundant taxon, represented by three infrageneric groups: Group Quercus (Plate I C-D), Group Quercus/ Lobatae (Plate I: E-H) and aff. Group Protobalanus (Plate I: I-J). The number of Quercus pollen grains reaches $>50 \%$ in most samples, except those at $572.15 \mathrm{mbsf}$ and $570.02 \mathrm{mbsf}$ (Fig. 2). In addition, Eotrigonobalanus is also part of the microfloristic assemblage (Plate I, K-L; Supplement S4). Pollen of the subfamily Engelhardioideae (Juglandaceae) is also abundant (min:

$10 \quad 0.4 \%$, max: $21.7 \%$ ) and shows a decreasing trend towards Sequence m6 (20.9 - 20.7 Ma) (Fig. 2). Genera such as Liquidambar, Elaeagnus (Supplement S4), Acer, Fagus, Nyssa or Artemisia are sporadically present as are spores of pteridophytes. The most abundant palynomorphs are the gymnosperms Pinus ( $0.4 \%$ to $32.7 \%$ ) and Cathaya (0 \% to $27.1 \%)$. Pollen grains of Pinus subg. Strobus outnumbered Pinus subg. Pinus in all samples (Fig. 2). The subdivision of Pinus at subgeneric level and of bisaccate pollen in general was often hindered by limited preservation. The sum of bisaccate

15 representatives fluctuated through the entire analysed time interval and reached the highest relative abundance of $120.8 \%$ at 533.45 mbsf (Fig. 3). The Shannon-Wiener Index (H(s)), generally varied between 1 and 2 indicating relative low diversity, but shows distinct peaks $>2$ between 560.01-572.15 mbsf, 529.97-533.54 mbsf and 495.72-495.91 mbsf (Fig. 3).

\subsection{Estimated palaeoclimate of NJSS}

The bioclimatic analysis indicates humid warm-temperate climatic conditions for the entire dataset (Fig. 4). Average estimated

20 MAT for the entire record was $14.6{ }^{\circ} \mathrm{C} \pm 4.0^{\circ} \mathrm{C}$. Palaeoclimatic estimates of CMMT are $5.2^{\circ} \mathrm{C} \pm 5.3{ }^{\circ} \mathrm{C}$ and of WMMT $24.1{ }^{\circ} \mathrm{C}$ $\pm 2.9^{\circ} \mathrm{C}$ in average. All average palaeoclimatic estimations of each individual sequence are summarized in Table 1 . The palaeoclimatic conditions of the New Jersey hinterland remained relatively constant over the preserved interval. Considering each investigated sequence individually, an average weak cooling and warming is reflected within the humid warm-temperate climate. Around the OMB (Fig. 4) between $\sim 533 \mathrm{mbsf}$ and $\sim 529 \mathrm{mbsf}$ a stepwise decline to lower temperatures is reflected

25 (MAT and WMMT $\sim-3^{\circ} \mathrm{C}$; CMMT $\sim-5^{\circ} \mathrm{C}$ ). The only estimated palaeoclimatic parameter which remained fairly constant over the analysed time is MAP (Fig. 4), reflecting humid conditions (always $>1000 \mathrm{~mm}$ ).

\section{Discussion}

\subsection{Taphonomy of terrestrial palynomorphs}

Deposition of terrestrial palynomorphs in marine sediments depends on multiple factors (e.g. pollen production, transport mechanisms, shoreline distance; van der Kaars, 2001). Studies concerning deposition of pollen and spores in neritic marine 
Biogeosciences Discuss., https://doi.org/10.5194/bg-2017-511

Manuscript under review for journal Biogeosciences

Discussion started: 11 January 2018

(c) Author(s) 2018. CC BY 4.0 License.

sediments (Mudie and McCarthy, 1994; van der Kaars, 2001) indicate a reliable comparability of the microfloristic assemblage in marine sediments with the contemporary onshore vegetation. Because the palaeo-shelf break only transgressed the Site M0027 during the Early Miocene (McCarthy et al., 2013) dominance of bisaccate grains is expected, reflecting their preferential transport in wind and water (McCarthy et al., 2003).

5 Today the most important transport mechanism of pollen and spores into the marine realm along the North American coast are the westerlies (Mudie and McCarthy, 1994). Prevailing westerly winds were probably already established since the middle Oligocene. A further, but subordinate transport mechanism is pollen input via rivers and streams into the NJSS. Fluvial influence has been identified based on the sedimentological record (Miller et al., 2013a) for the NJSS. Downslope mass transport is not expected to be a major factor at Site M0027 prior to the transgression of the shelf break within sedimentary

10 Unit 6/sequence m5.8 (Fig. S1), except during glacioeustatic lowstands - then the ratio of terrestrial vs. marine palynomorphs (“P:D”) helps identify resedimentation (McCarthy et al., 2013).

\subsection{Palaeoforest composition of the New Jersey hinterland}

Our results indicate that the Oligocene hinterland of the NJSS was covered by dense forests, with mesophytic forest growing on dry soils being the most widespread and diverse forest type on areas of low relief. Topographic higher elevations, and/or

15 drier areas were probably inhabited by conifers such as Pinaceae. Oaks (Quercus spp.) are the main element dominating the mesophytic forest of eastern North America in the past and at present (Abrams, 1992). Today $\sim 90$ different Quercus species are found in North America of which $\sim 35$ species are present in eastern North America (eFloras, 2008). Quercus probably appeared during the early Eocene (Grímsson et al., 2016 and references therein).

A late Eocene to early Oligocene palynofloristic record from southern Mississippi and Alabama (Oboh and Reeves Morris, 1994; Oboh et al., 1996) revealed that oaks became dominant at the Eocene-Oligocene boundary in the southeastern USA, probably indicating a vegetation shift triggered by cooling, as already suggested by Frederiksen (1991). In North America, the fossil record of Quercus implies that four infrageneric groups had existed during the Cenozoic (Denk et al., 2010 and references therein). Three of them persist in the modern North American vegetation, and two of these (Group Lobatae and Quercus) exist east of the Cordillera (eFloras, 2008). The analysed Quercus pollen grain sculptures from our study have affinities with Group Quercus (white oaks; Plate I, C-D), Quercus/ Lobatae (white/ red oaks; Plate I, E-H) and aff. Group Protobalanus (golden-cup oaks; Plate I, I-J). These findings suggest the presence of a diverse Quercus population at subgeneric level during the Oligocene. Alternatively, the pollen ornamentation of Group Protobalanus may also indicate an ancestral lineage of the Protobalanus-Quercus-Lobatae clade (Grímsson et al., 2015).

The NJSS microfloristic assemblage also suggests the presence of Eotrigonobalanus (Plate I, K- L), an extinct Fagaceae 30 lineage. Eotrigonobalanus was a typical member of evergreen forests of the Palaeogene and flourished in different ecological habitats (Walther, 2000). The fossil record of Eotrigonbalanus in North America is very fragmentary (Grímsson et al., 2016). In Europe, Eotrigonobalanus was an accessory element within the evergreen forest and became dominant during the Late Eocene (Walther, 2000). In situ pollen grains from Texas referred to as Amentoplexipollenites (late Rupelian to Chattian; 
Biogeosciences Discuss., https://doi.org/10.5194/bg-2017-511

Manuscript under review for journal Biogeosciences

Discussion started: 11 January 2018

(c) Author(s) 2018. CC BY 4.0 License.

Crepet and Nixon, 1989) are very similar with those of our investigation as well as with Eotrigonobalanus pollen grains of Central Europe (Denk et al., 2012). After Grímsson et al. (2016) a main characteristic difference between Amentoplexipollenites (Crepet and Nixon, 1989) and pollen grains of Eotrigonobalanus from British Columbia (Eocene) and Wyoming (Cretaceous) is the much thinner nexine of the latter. Evidence for the existence of Triogobalanopsis, another extinct

5 Fagaceae lineage in North America, is known from British Columbia (Eocene; Grímsson et al., 2016). All analysed pollen grains encountered in this study belonged to Eotrigonobalanus, however, we cannot rule out that this extinct lineage flourished in the New Jersey hinterland too.

Oaks are relatively persistent floristic elements within the mesophytic forest when comparing the Oligocene and late MidMiocene (Prader et al., 2017); however, significant floristic shifts within the mesophytic forest occurred. Relative abundances

10 of pollen grains of Engelhardioideae or Carya in our investigation reveal similar values when compared to data from the eastern coast of the Gulf of Mexico and South Carolina for the Late Eocene/Early Oligocene (Frederiksen, 1991; Oboh and Reeves Morris, 1994; Oboh et al., 1996). The recorded pollen percentages differ significantly from the values revealed for the late Mid-Miocene (Prader et al., 2017).

The Engelhardioideae (Juglandaceae) might have had a greater ecological range in the Oligo-Miocene than reflected by their

15 living representatives (Kvaček, 2007). However, the decreasing relative abundance of Engelhardioideae pollen in the longterm trend from the middle Oligocene to the late Miocene reveals that this group was not as competitive as other taxa concerning environmental changes. Accordingly, this group is not prominent any more in the pollen record of the late MidMiocene (Prader et al., 2017). If the drop of relative abundances of the Engelhardioideae was temperature-dependent, subsequent cooling events after the Mi-1 inception were probably necessary to induce the disappearance of the taxon (Prader 20 et al., 2017).

In comparison, other tree taxa like Fagus or Liquidambar were more constant elements of the mesophytic forest of the Miocene (Prader et al., 2017) than during the Oligocene. The fossil records of Fagus (Denk and Grimm, 2009) and Liquidambar (Manchester, 1999) for the Oligocene are fragmentary. These genera were also not prevalent in the New Jersey hinterland during the analysed time interval.

25 Fagus appeared the first time in the fossil record during the late early Eocene in western North America (Manchester and Dillhoff, 2005) and was continuously widespread during the late Oligocene in the western part of the continent and Europe (Kvaček and Walther, 1991). Its radiation and diversification led to a first occurrence peak in the Miocene (Denk and Grimm 2009). Our investigations indicate that Fagus was only a minor vegetation element in the hinterland of the NJSS during the early Miocene, but was a persistent component during the Mid-Miocene (Prader et al., 2017). Like today, the east coast of North America was never a centre of biodiversity of beeches.

Contrary to Fagus and its spatiotemporal distribution, the Atlantic east coast is currently a hot spot of biodiversity of the genus Carya (Wen, 1999). In our record, the relative occurrences of this genus were as low as those of Fagus. Carya first appeared in the Palaeocene in North America (Manchester, 1987) and the first radiation began in the early Miocene (Zhang et al., 2013). Zhang et al. (2013) suggest that the Appalachian uplift phases created new habitats, which led to a diversification of the genus. 
Biogeosciences Discuss., https://doi.org/10.5194/bg-2017-511

Manuscript under review for journal Biogeosciences

Discussion started: 11 January 2018

(c) Author(s) 2018. CC BY 4.0 License.

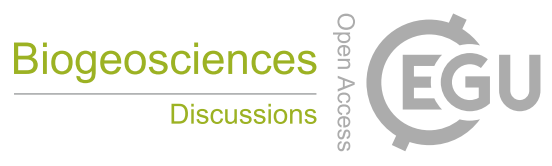

(c) (i)

This might explain the increase of the pollen grain counts of Carya in the Mid-Miocene where Carya became the prevalent genus of the Juglandaceae (Prader et al., 2017).

4.3 Terrestrial ecosystem responses to glacial events of the Mid-Oligocene to the Early Miocene.

The entire Oligocene epoch is characterized by periodic climate oscillations associated with orbital insolation changes (Pälike

5 et al., 2006). These orbital climate changes triggered the built-up and decay of Antarctic Ice Sheets, leading to substantial glacioeustatic sea level oscillations (Pekar et al., 2002, 2006; Wade and Pälike, 2004, Pälike et al., 2006).

Reconstructions of bottom water temperatures in the equatorial Pacific ( $\mathrm{Mg} / \mathrm{Ca}$ temperature records of Site 1218) indicate low temperature variations for the Oligocene (on average $3.7^{\circ} \mathrm{C} \pm 1.5^{\circ} \mathrm{C}$; Lear et al., 2004). However, rapid cooling of $2{ }^{\circ} \mathrm{C}$ is associated with isotope events Oi- $2 \mathrm{~b}$ and Mi-1 (Lear et al., 2004). Although the limited temporal resolution of our record from

10 the NJSS inhibits the evaluation of vegetation responses to periodic orbital changes, it may be used to test the potential impacts of particularly strong Oligocene climate shifts. Specifically, fluctuations of the relative abundances of vegetation units can be interpreted in terms of possible movement signals.

However, the indications of such signals within the terrestrial palynomorph signature are weak. Possibly distinct marine influence hampered the regional impact by moderating the global climate changes.

15 Our reconstructed palaeoclimate shows humid-warm temperate conditions under which only little altitudinal shifts took place. One example for a altitudinal movement signal could be the first peak of the meso- and microthermal Pinaceae (Fig. 4) at 29.3 $-29.0 \mathrm{Ma}$. The most plausible explanation for this peak might be the impact of the unnamed $\delta^{18} \mathrm{O}$ excursion at $\sim 29.1$ in the records from New Jersey (Pekar et al., 2002) and from the tropical Pacific (Site 1218: Wade and Pälike, 2004). However, relative pollen abundances of Vegetation Unit 4 remained relative stable (Fig. 3), indicating that either the amplitude of climatic

20 factors (e.g. cooling) was too small to induce a strong reduction of the mesophytic forest or the regional vegetation units had a high degree of resilience to the climate forcing.

The first noteworthy reduction of Vegetation Unit 4 and a simultaneous increase of bisaccate Pinaceae probably coincide with the Oi2-a event at $\sim 28.3 \mathrm{Ma}$ (Pekar et al., 2002) and/or the $\sim 28.5-\mathrm{Ma}-\delta^{18} \mathrm{O}$ increase (Pekar et al., 2002). The conifers spread into the lowland and partly replaced Vegetation Unit 4 (Fig. 3). The idea of downward movement of the conifers is reinforced

25 by the negatively correlating P:D ratio, which indicates an increasing shoreline vicinity and thus only a low chance of transportinduced increase in bisaccate pollen percentages.

Differing to the placing of the Mi-1 event at 23.03 Ma based on orbital tuning (Liebrand et al., 2011), it was placed at 23.8 Ma at the New Jersey margin by Pekar et al. (2002), who postulate an apparent sea-level drop of $56 \mathrm{~m}$ connected to the Mi-1 event. A definitive placement of the Mi-1 event is however difficult for Site M0027, since it probably corresponded with a strong 30 sea-level lowstand creating the sequence boundary of Sequence O6 (Browning et al., 2013). The increased input of bisaccate pollen at the beginning of Sequence O6 (probably around the OMB) is consistent with findings of Kotthoff et al. (2014) which indicate that abiotic factors ameliorated the expansion of conifers (Vegetation Units 1 and 2) and led to a relative decrease of Vegetation Unit 4 (mesophytic forest, Fig. 3). 
Biogeosciences Discuss., https://doi.org/10.5194/bg-2017-511

Manuscript under review for journal Biogeosciences

Discussion started: 11 January 2018

(c) Author(s) 2018. CC BY 4.0 License.

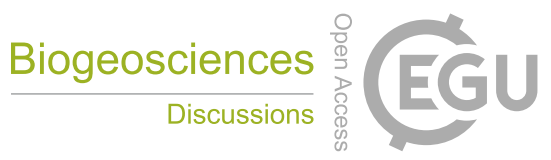

(c) (i)

A temperature drop might be visible within all parameters at $\sim 530 \mathrm{mbsf}$ in our data, with a stepwise MAT-decline of $\sim 3^{\circ} \mathrm{C}$. It probably matches with the MAT-drop of $\sim 4^{\circ} \mathrm{C}$ described by Kotthoff et al. (2014) at the same depth. A coeval increase of Vegetation Unit 7 (coastal), probably reflecting dryer and cooler conditions, is also consistent with Kotthoff et al. (2014). However, MAP does not decrease around this time interval, the dataset rather suggests an average overall stable trend in 5 precipitation suggesting more occupation of coastal plain. A further decline of Unit 4 occurred within Sequence m6 ( 20.9$20.7 \mathrm{Ma}$; Fig. 3), probably reflecting a late Aquitanian vegetation change provoked by the unnamed $\delta^{18} \mathrm{O}$ increase at $\sim 20.8 \mathrm{Ma}$ (Browning et al., 2013).

The generally fluctuating patterns of Vegetation Units 3 and 4 and of the $(\mathrm{H}(\mathrm{s}))$-Index represent indirect confirmation of climate change in the hinterland of the NJSS in phase with depositional changes of the Oligocene and early Miocene sediment

10 succession at Site M0027. Peaks of Vegetation Units 5 and 3 coincide with all regression phases (glacial phases) discussed above, which exposed shallow shelf areas allowing for the spreading of substrate-depending forest formations (Fig. 3). The simultaneous expansion of Vegetation Units 3 and 5 percentages and concomitant increase of the (H(s))-Index indicate a quite diverse low elevation forest and thus a decreasing distance to the shoreline, facilitating pollen grain input during regression phases and/or a larger altitudinal gradient.

\section{5. Conclusion}

The comparison of recorded pollen percentages of this investigation with the late Mid-Miocene values (Prader et al., 2017), revealed a contrasted spatiotemporal distribution of mesic taxa in the New Jersey hinterland, probably caused by changing environmental conditions which in the long-term trend led to an enhanced floristic turnover. The presence of different pollen grain sculptures within the genus Quercus suggests a diverse Quercus population at subgeneric level. The relatively high abundances of Quercus pollen grains emphasise the dominance and significance of this taxon within the mesophytic forest. The sporadic occurrence of the extinct Fagaceae genus Eotrigonobalanus in the New Jersey hinterland widens the understanding of its distribution pattern in the Northern Hemisphere during the Cenozoic. The bioclimatic analysis reveals a relative climatic stability during the middle Oligocene to Early Miocene reflecting within humid warm temperate condition. However, a stepwise weak cooling signal during this interval is reflected in calculated MAT, WMMT and CMMT and might 25 correspond to the Mi-1 event (MAT and WMMT $\sim-3^{\circ} \mathrm{C}$; CMMT $\sim-5^{\circ} \mathrm{C}$ ).

The limited temporal resolution of our pollen record from the NJSS inhibited the evaluation of vegetation responses to periodic orbital changes of the Oligocene and Early Miocene. Nevertheless, the terrestrial palynomorph signature demonstrate weak fluctuations signals through these time intervals, which allow the interpretation in terms of possible movement signals caused by periodic climate oscillations. The observed movement signals of different intensions are probably best reflected within

30 peaks of meso- and microthermal Pinaceae, probably corresponding to the unnamed $\delta^{18} \mathrm{O}$ excursion at $\sim 29.1$, the Oi2-a event at $\sim 28.3 \mathrm{Ma}$ and/or the $\sim 28.5$-Ma- $-\delta^{18} \mathrm{O}$ increase and to the Mi-1 event at $\sim 23.8 \mathrm{Ma}$. Regression phases (glacial phases) exposed 
Biogeosciences Discuss., https://doi.org/10.5194/bg-2017-511

Manuscript under review for journal Biogeosciences

Discussion started: 11 January 2018

(c) Author(s) 2018. CC BY 4.0 License. and 4 during glacial phases represented thus an indirect confirmation of climate change.

\section{Acknowledgements}

We thank the entire Integrated Ocean Drilling Program (IODP) Expedition 313 Scientific Party and the staff of the IODP Core

5 Repository Bremen. We acknowledge A. Krueger, Palynology Lab at Brock University; E. Czymoch and K. A. Harps, University of Hamburg, for sample processing and Y. Milker, M. Theodor and R. Walter, for support at the SEM and J. Reolid for sea level oscillations discussion. The research was supported by the German Science Foundation (DFG; Project Ko 3944/5). DRG's participation was further supported by a grant from the Natural Sciences and Engineering Research Council of Canada (RGPIN 2016-04337).

\section{7. Author contributions}

Author contributions: U.K. and F.M.G.M had the research idea, S.P. wrote the MS with substantial contributions of all authors. S.P. counted and analysed data with support of T.D. (pollen identification), G.S. (statistical analyses) and D.R.G. (bioclimatic analyses).

\section{References}

15 Abrams, M. D.: Fire and the Development of Oak Forests, BioScience, 42, 346-353, 1992.

Browning, J. V., Miller, K. G., Sugarman, P. J., Barron, J., McCarthy, F. M. G., Kulhanek, D. K., Katz, M. E., and Feigenson, M. D.: Chronology of Eocene-Miocene sequences on the New Jersey shallow shelf: implications for regional, interregional, and global correlations, Geosphere, 9, 1434-1456, 2013.

Coxall, H. K., Wilson, P. A., Palike, H., Lear, C. H. and Backman, J.: Rapid stepwise onset of Antarctic glaciation and deeper calcite compensation in the Pacific Ocean, Nature, 433, 53-57, 2005.

Crepet, W. L. and Nixon, K. C.: Extinct Transitional Fagaceae from the Oligocene and their Phylogenetic Implications, Am. J. Bot., 76, 1493-1505, 1989.

Denk, T. and Grimm, G. W.: The biogeographic history of beech trees, Rev. Palaeobot. Palynol., 158, 83-100, 2009.

Denk, T., Grímsson, F. and Zetter, R.: Episodic migration of oaks to Iceland: Evidence for a North Atlantic "land bridge" in 25 the latest Miocene, Am. J. Bot., 97, 276-287, 2010.

Denk, T., Grímsson, F. and Zetter, R.: Fagaceae from the early Oligocene of Central Europe: Persisting new world and emerging old world biogeographic links, Rev. Palaeobot. Palynol.,169, 7-20, 2012.

eFloras. Flora of North America.: http://www.efloras.org; accessed March-June 2017, 2008. 
Biogeosciences Discuss., https://doi.org/10.5194/bg-2017-511

Manuscript under review for journal Biogeosciences

Discussion started: 11 January 2018

(c) Author(s) 2018. CC BY 4.0 License.

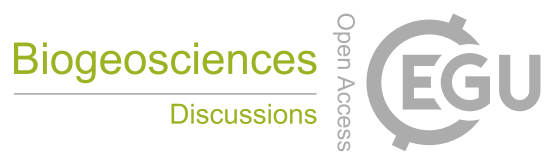

(c) (i)

Eldrett, J. S., Greenwood, D. R., Harding, I. C. and Huber, M.: Increased seasonality through the Eocene to Oligocene transition in northern high latitudes, Nature, 459, 969-973, 2009.

Expedition 313 Scientist.:, Site M0027A. in Mountain, G., Proust, J.-N., McInroy, D., Cotterill, C., and the Expedition 313 Scientists, eds., Proceedings of the Integrated Ocean Drilling Program. Expedition 313: Tokyo, Integrated Ocean Drilling

5 Program Management International, Inc., pp. 148, 2010.

Frederiksen, N. O.: Pulses of Middle Eocene to Earliest Oligocene Climatic Deterioration in Southern California and the Gulf Coast, Palaios, 6, 564-571, 1991.

Graham, A.: Late Cretaceous history of North America vegetation: north of Mexico, Oxford University Press on Demand, pp. $350,1999$.

10 Greenwood, D. R., Archibald, S. B., Mathewes, R. W. and Moss, P. T.: Fossil biotas from the Okanagan Highlands, southern British Columbia and northeastern Washington State: climates and ecosystems across an Eocene landscape, Can. J. Earth Sci., 42, 167-185, 2005.

Grímsson, F., Zetter, R., Grimm, G. W., Pedersen, G. K., Pedersen, A. K. and Denk, T.: Fagaceae pollen from the early Cenozoic of West Greenland: revisiting Engler's and Chaney's Arcto-Tertiary hypotheses, Plant Syst. Evol., 301, 809-832,

152015.

Grímsson, F., Grimm G. W., Zetter, R. and Denk, T.: Cretaceous and Paleogene Fagaceae from North America and Greenland: evidence for a Late Cretaceous split between Fagus and the remaining Fagaceae, Acta Palaeobot., 56, 247-305, 2016.

Hably, L., Kvaček, Z. and Manchester, S.R.: Shared taxa of land plants in the Oligocene of Europe and North America in context of Holarctic Phytogeography, Acta Univ. Carol. Geol., 44, 59-74, 2000.

20 Kmenta, M. and Zetter, R.: Combined LM and SEM study of the upper Oligocene/lower Miocene palynoflora from Altmittweida (Saxony): Providing new insights into Cenozoic vegetation evolution of Central Europe, Rev. Palaeobot. Palynol.,195, 1-18, 2013.

Kotthoff, U., Greenwood, D. R., McCarthy, F. M. G., Müller-Navarra, K., Prader, S. and Hesselbo, S. P.: Late Eocene to middle Miocene (33 to 13 million years ago) vegetation and climate development on the North American Atlantic Coastal

25 Plain (IODP Expedition 313, Site M0027), Clim. Past, 10, 1523-1539, 2014.

Kovar-Eder, J.: Early Oligocene plant diversity along the Upper Rhine Graben: The fossil flora of Rauenberg, Germany, Acta Palaeobot. 56, 329-440, 2016.

Kvaček, Z. and Walther H.: Revision der mitteleuropäischen tertiären Fagaceen nach blattepidermalen Charakteristiken. IV. Teil Fagus Linné, Feddes Repert., 102, 471-534, 1991.

30 Kvaček, Z.: Do extant nearest relatives of thermophile European Cenozoic plant elements reliably reflect climatic signal? Palaeogeogr. Palaeoclimatol. Palaeoecol., 253, 32-40, 2007.

Lear, C. H., Rosenthal, Y., Coxall, H. K. and Wilson, P. A.: Late Eocene to early Miocene ice sheet dynamics and the global carbon cycle, Paleoceanography, 19, PA4015, doi:10.1029/2004PA001039, 2004. 
Biogeosciences Discuss., https://doi.org/10.5194/bg-2017-511

Manuscript under review for journal Biogeosciences

Discussion started: 11 January 2018

(c) Author(s) 2018. CC BY 4.0 License.

Liu, L.: Rejuvenation of Appalachian topography caused by subsidence-induced differential erosion, Nature Geoscience, 7, 518-523, 2014.

Liebrand, D., Lourens, L. J., Hodell, D. A., de Boer, B., van de Wal, R. S. W. and Pälike, H.: Antarctic ice sheet and oceanographic response to eccentricity forcing during the early Miocene, Clim. Past, 7, 869-880, 2011.

5 Manchester, S. R.: The fossil history of the Juglandaceae, Monogr. Syst. Bot., 21, 1987.

Manchester, S. R.: Biogeographical relationships of North American Tertiary floras, Ann. Mo. Bot. Gard., 86, 472-522, 1999.

Manchester, S. R. and Dillhoff, R. M. Fagus (Fagaceae) fruits, foliage, and pollen from theMiddle Eocene of Pacific northwestern North America, Can. J. Bot., 82, 1509-1517, 2005.

McCarthy, F. M. G., Gostlin, K. E., Mudie, P. J. and Hopkins, J.: Terrestrial and marine palynomorphs as sea-level proxies:

10 an example from Quaternary sediments on the New Jersey margin, in Olson, H.C. and Leckie, M., eds. "Micropaleontologic Proxies for Sea-Level Change and Stratigraphic Discontinuities”, SEPM Special Publication No. 75, 119-129, 2003.

McCarthy, F.M.G., Katz, M.E., Kotthoff, U., Browning, J.V., Miller, K.G., Zanatta, R., Williams, R.H., Drljepan, M., Hesselbo, S.P., Bjerrum, C.J., Mountain, G.S.: Sea-level control of New Jersey margin architecture: Palynological evidence from Integrated Ocean Drilling Program Expedition 313, Geosphere 9, 1457-1487, 2013.

15 Meyer, H. W. and Manchester, S. R.: The Oligocene Bridge Creek Flora of the John Day Formation, Oregon, Vol. 141, University of California publications in geological sciences, Berkeley, Los Angeles, London, pp. 195, 1997.

Miller, K.G., Browning, J.V., Mountain, G.S., Bassetti, M.A., Monteverde, D., Katz, M.E., Inwood, J., Lofi, J., Proust, J.-N.: Sequence boundaries are impedance contrasts: Core-seismic-log integration of Oligocene-Miocene sequences, New Jersey shallow shelf, Geosphere 9, 1257-1285, 2013a.

20 Miller, K. G., Mountain, G. S., Browning, J. V., Katz, M. E., Monteverde, D., Sugarman, P. J., Ando, H., Bassetti, M. A., Bjerrum, C. J., Hodgson, D., Hesselbo, S., Karakaya, S., Proust, J.-N., Rabineau, M.: Testing sequence stratigraphic models by drilling Miocene foresets on the New Jersey shallow shelf, Geosphere 9, 1236-1256, $2013 \mathrm{~b}$.

Mountain, G., Proust, J.-N., McInroy, D., Cotterill, C. and the Expedition 313 Scientists.: Proceedings of the Integrated Ocean Drilling Program. Expedition 313: Tokyo, Integrated Ocean Drilling Program Management International, Inc., doi:10.2204/iodp.proc.313.101.2010, 2010.

Mudie, P. J. and McCarthy, F. M. G.: Late Quaternary pollen transport processes, western North Atlantic: Data from box models, cross-margin and N-S transects, Mar. Geol., 118, 79-105, 1994.

Oboh, F. E. and Reeves Morris, L. M.: Early Oligocene Palynosequences in the Eastern Gulf Coast, U.S.A, Palynology, 18, 213-235, 1994.

30 Oboh, F. E., Jaramillo, C. A. and Reeves Morris, L. M.: Late Eocene-Early Oligocene paleofloristic patterns in southern Mississippi and Alabama, US Gulf Coast, Rev. Palaeobot. Palynol., 91, 23-34, 1996.

Pagani, M., Zachos, J. C., Freeman, K. H., Tipple, B. and Bohaty, S.: Marked Decline in Atmospheric Carbon Dioxide Concentrations During the Paleogene, Science, 309, 600-603, 2005. 
Biogeosciences Discuss., https://doi.org/10.5194/bg-2017-511

Manuscript under review for journal Biogeosciences

Discussion started: 11 January 2018

(c) Author(s) 2018. CC BY 4.0 License.

Pälike, H., Norris, R. D., Herrle, J. O., Wilson, P. A., Coxall, H. K., Lear, C. H., Shackleton, N. J., Tripati, A. K., and Wade, B. S.: The Heartbeat of the Oligocene Climate System, Science, 314, 1894-1898, 2006.

Pekar, S. F., Christie-Blick, N., Kominz, M. A., \& Miller, K. G.: Evaluating the stratigraphic response to eustasy from Oligocene strata in New Jersey, Geology, 29, 55-58, 2001.

5 Pekar, S. F., Christie-Blick, N., Kominz, M. A. and Miller, K. G.: Calibration between eustatic estimates from backstripping and oxygen isotopic records for the Oligocene, Geology, 30, 903-906, 2002.

Pekar, S. F., DeConto, R. M. and Harwood, D. M.: Resolving a late Oligocene conundrum: Deep-sea warming and Antarctic glaciation, Palaeogeogr. Palaeoclimatol. Palaeoecol., 231, 29-40, 2006.

Prader, S., Kotthoff, U., McCarthy, F. M. G., Schmiedl, G., Donders, T. H. and Greenwood, D. R.: Vegetation and climate

10 development of the New Jersey hinterland during the late Middle Miocene (IODP Expedition 313 Site M0027), Palaeogeogr. Palaeoclimatol. Palaeoecol., 485, 854-868, 2017.

Prebble, J. G., Reichgelt, T., Mildenhall, D. C., Greenwood, D. R., Raine, J. I., Kennedy, E. M. and Seebeck H. C.: Terrestrial climate evolution in the Southwest Pacific over the past 30 million years, Earth Planet. Sci. Lett., 459, 136-144, 2017.

Retallack, G. J., Orr, W. N., Prothero, D. R., Duncan, R. A., Kester, P. R. and Ambers, C. P.: Eocene-Oligocene extinction

15 and paleoclimatic change near Eugene, Oregon, Geol. Soc. Am. Bull., 116, 817-839, 2004.

Roth-Nebelsick, A., Oehm, C., Grein, M., Utescher, T., Kunzmann, L., Friedrich, J.-P. and Konrad W.: Stomatal density and index data of Platanus neptuni leaf fossils and their evaluation as a CO2 proxy for the Oligocene, Rev. Palaeobot. Palynol., 206, 1-9, 2014.

Scher, H. D. and Martin, E. E.: Timing and Climatic Consequences of the Opening of Drake Passage, Science, 312, 428-430, 202006.

Schlitzer, R.: Ocean Data View, http://odv.awi.de, 2011.

Scotese, C. R., Gahagan, L. M. Larson, R. L.: Plate tectonic reconstructions of the Cretaceous and Cenozoic ocean basins, Tectonophysics, 155, 27-48, 1988.

Strömberg, C. A. E.: Decoupled taxonomic radiation and ecological expansion of open-habitat grasses in the Cenozoic of

25 North America, Proc. Nat. Acad. Sci., 102, 11980-11984, 2005.

US Climate Data.: https://www.usclimatedata.com; accessed November 2017, .....

Utescher, T., Bondarenko, O. V. and Mosbrugger, V.: The Cenozoic Cooling - continental signals from the Atlantic and Pacific side of Eurasia, Earth Planet. Sci. Lett., 415, 121-133, 2015.

van der Kaars, S.: Pollen distribution in marine sediments from the south-eastern Indonesian waters, Palaeogeogr.

Palaeoclimatol. Palaeoecol., 171, 341-361, 2001.

von der Heydt, A. and Dijkstra, H. A.: Effect of ocean gateways on the global ocean circulation in the late Oligocene and early Miocene, Paleoceanography, 21, PA1011, doi:10.1029/2005PA00114, 2006.

Velitzelos, D., Bouchal, J. M. and Denk, T.: Review of the Cenozoic floras and vegetation of Greece. Rev. Palaeobot. Palynol., 204, 56-117, 2014. 
Biogeosciences Discuss., https://doi.org/10.5194/bg-2017-511

Manuscript under review for journal Biogeosciences

Discussion started: 11 January 2018

(c) Author(s) 2018. CC BY 4.0 License.

Wade, B. S. and Pälike, H.: Oligocene climate dynamics, Paleoceanography, 19, doi:10.1029/2004PA001042, 2004.

Walther, H.: Floristic relationship between North and Central America and Europe in the Eocene, Acta Univ. Carol. Geol., 44, $51-57,2000$

Wen, J.: Evolution of Eastern Asian and Eastern North American Disjunct Distributions in Flowering Plants, Annu. Rev. Eco.

5 Syst., 30, 421-455, 1999.

Wolfe, J. A. and Schorn, H. E.: Paleoecologic, paleoclimatic, and evolutionary significance of the Oligocene Creede flora, Colorado, Paleobiology, 15, 180-198, 1989.

Wolfe, J. A. and Schorn, H. E.: Taxonomic revision of the Spermatopsida of the Oligocene Creede flora, southern Colorado, U.S. Geological Survey Bulletin Report No.1923, 1990.

10 Zachos, J. C., Shackleton, N. J., Revenaugh, J. S., Pälike, H. and Flower, B. P.: Climate Response to Orbital Forcing Across the Oligocene-Miocene Boundary, Science, 292, 274-278, 2001.

Zhang, J-B., Li, R-Q., Xiang, X-G., Manchester, S.R., Lin, L, Wang, W., Wen, J., Chen, Z-D.: Integrated fossil and molecular data reveal the biogeographic diversification of the eastern Asian-eastern North American disjunct Hickory genus (Carya Nutt.), Plos One 8, e70449. doi:10.1371/journal.pone.0070449, 2013.Aman, A. A. and Bman, B. B.: The test article, J. Sci.

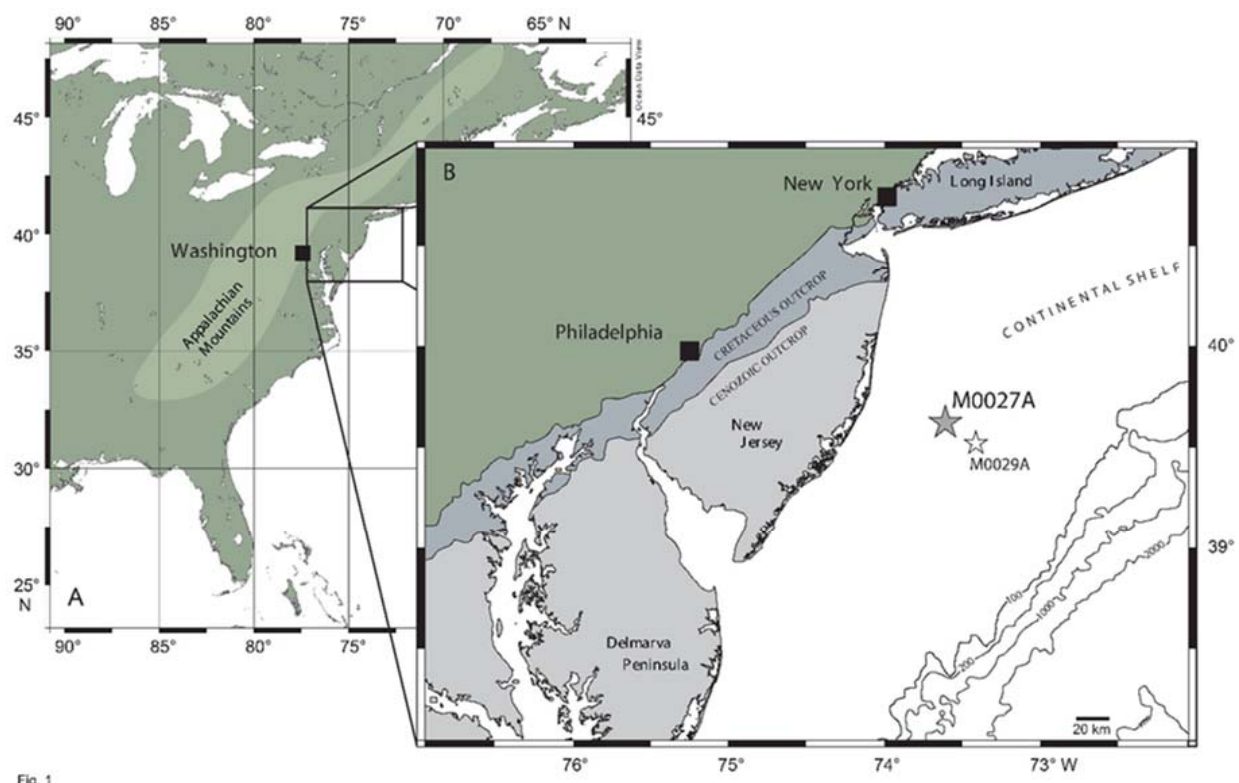

Figure 1. A. Location of the study area in eastern North America. B. Detailed map of the New Jersey area. Grey star indicates position of Site M0027, white star: position of Site M0029. After Mountain et al. (2010), Schlitzer (2011), Kotthoff et al. (2014). 
Biogeosciences Discuss., https://doi.org/10.5194/bg-2017-511

Manuscript under review for journal Biogeosciences

Discussion started: 11 January 2018

(c) Author(s) 2018. CC BY 4.0 License.

\section{(c) (1)}

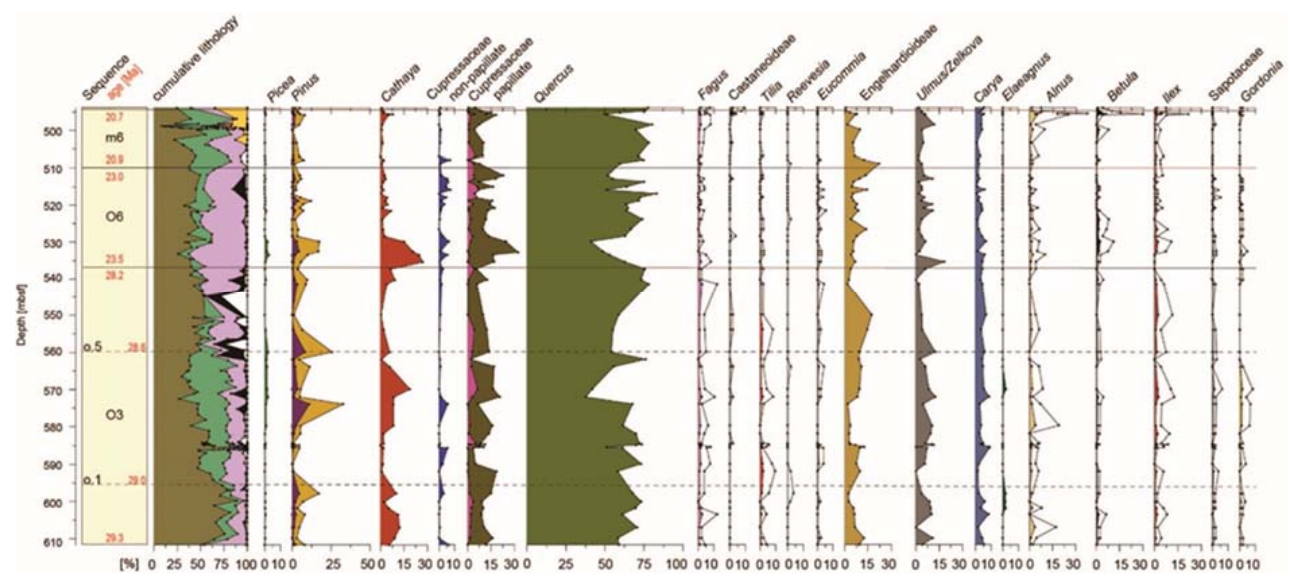

Figure 2. Relative abundances of selected pollen grain taxa for Site M0027A plotted against depth (pollen sum excluding bisaccates). Transparent areas in plots of Fagus, Tilia, Betula, Alnus, Ilex, Sapotaceae, Reevesia, Elaeagnus, Eucommia, Gordonia denote 5x exaggerated values. Pinus subg. Strobus: violet; Pinus subg. Pinus and unidentifiable Pinus pollen grains: yellow. Cupressaceae non5 papillate type: blue; Cupressaceae presumably with papilla: pink; Cupressaceae with a papilla: brown. Sequence boundaries and age model after Browning et al. (2013) and Miller et al. (2013a, 2013b) with dashed lines indicating intrasequences. Cumulative lithology after Miller et al. (2013a): brown: clay and silt; green: glauconite; violet: quartz sand; yellow: medium and coarser quartz sand; black: carbonate; white: mica and other.

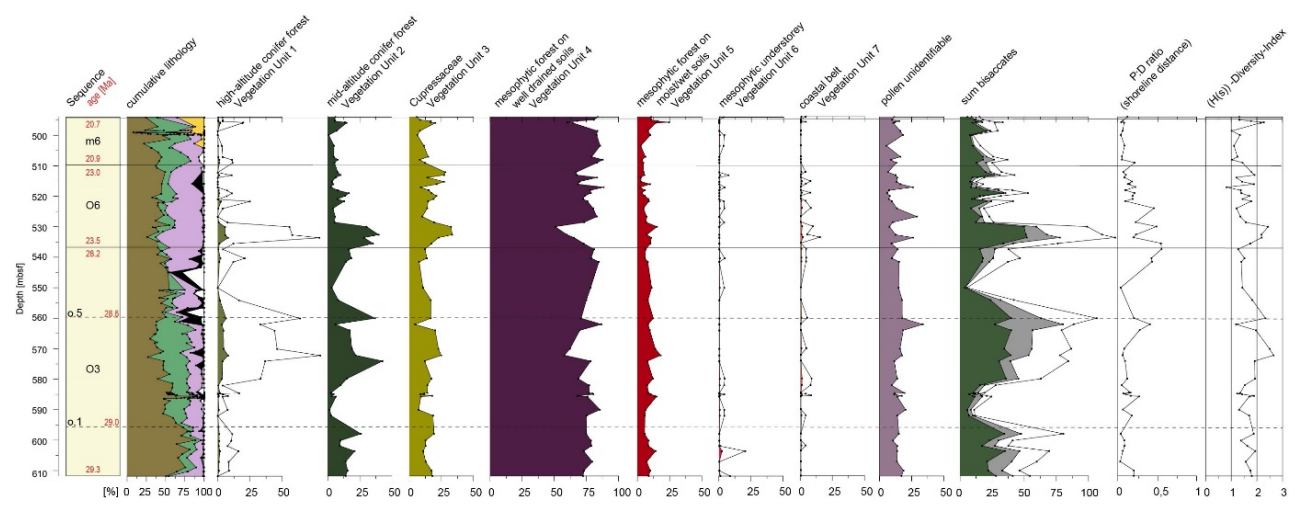

10 Figure 3. Vegetation units of the NJSS hinterland during the middle Oligocene to Early Miocene plotted against depth. Taxa are assigned as listed in Table S3 (transparent: 10x exaggerated: Vegetation Unit 1, Vegetation Unit 6, Vegetation Unit 7; sum of bisaccates: grey: unassigned bisaccate pollen grains; green: percentages of destroyed parts of bisaccate pollen grains $(\mathrm{H}(\mathrm{s}))$ Diversity-Index. Pollen-dinoflagellate ratio (P:D) indicating site-shoreline distance. Sequence boundaries and age model after Browning et al. (2013) and Miller et al. (2013a, 2013b): dashed lines: intrasequences. Cumulative lithology after Miller at al. (2013a):

15 brown: clay and silt; green: glauconite; violet: quartz sand; yellow: medium and coarser quartz sand; black: carbonate; white: mica and other. 
Biogeosciences Discuss., https://doi.org/10.5194/bg-2017-511

Manuscript under review for journal Biogeosciences

Discussion started: 11 January 2018

(c) Author(s) 2018. CC BY 4.0 License.

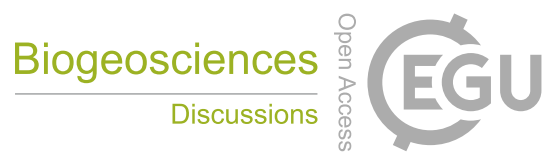

(c) (i)
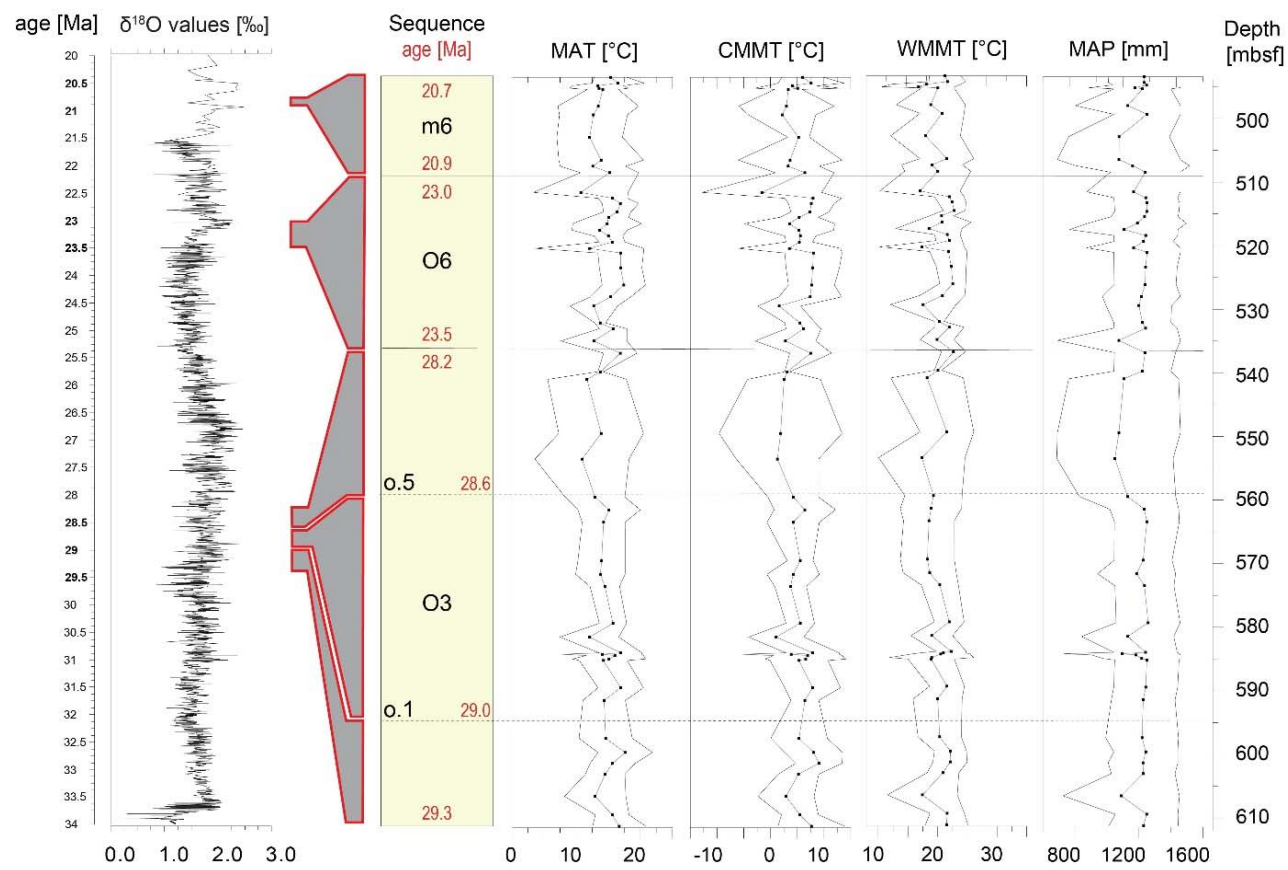

Figure 4. Calculated palaeoclimate during the middle Oligocene and early Miocene for the hinterland of the NJSS based on identified pollen grains from Site M0027 following the bioclimatic analysis after Greenwood et al. (2005) and Prebble et al. (2017) plotted against depth. Compared with $\delta^{18} \mathrm{O}$ values of ODP Site 1218 (equatorial Pacific) after Wade and Pälike (2004) plotted against age.

5 Please consider the different age models. MAT: mean annual temperature; CMMT: coldest moth mean temperature; WMMT: warmest month mean temperature and MAP: mean annual precipitation; outer lines: error of estimated values (present day climate parameters of Toms River (New Jersey): MAT 11.7 C ${ }^{\circ}$; CMMT: $5.7 \mathrm{C}^{\circ}$; WMMT: $17.7 \mathrm{C}^{\circ}$; MAP: 1239 mm, after US Climate Data, 2017) 
Biogeosciences Discuss., https://doi.org/10.5194/bg-2017-511

Manuscript under review for journal Biogeosciences

Discussion started: 11 January 2018

(c) Author(s) 2018. CC BY 4.0 License.

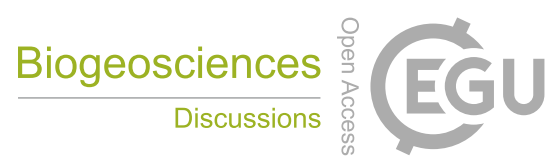

(c) (i)
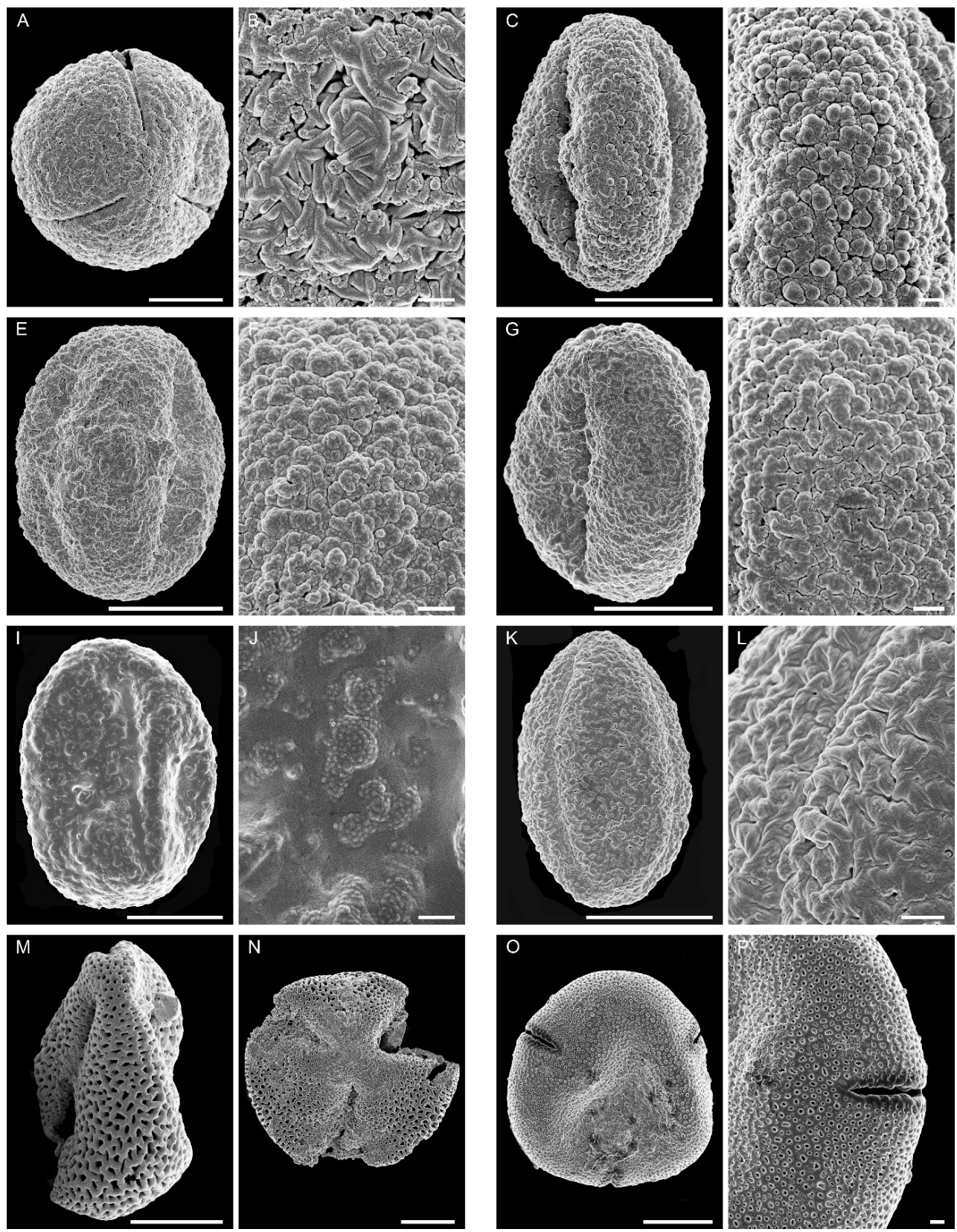

17 
Biogeosciences Discuss., https://doi.org/10.5194/bg-2017-511

Manuscript under review for journal Biogeosciences

Discussion started: 11 January 2018

(c) Author(s) 2018. CC BY 4.0 License.

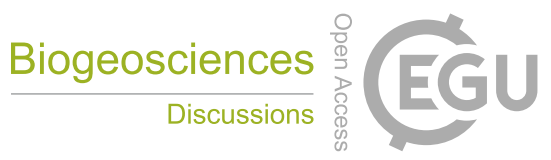

(c) (i)

Plate I SEM images of selected pollen grains of Site M0027A (574.05 mbsf). Overview (A, C, E, G, I, K, M, N O) and detail (B, D, F, H, J, L, P). A-B: Fagus; C-D: Quercus Group Quercus; E-H: Quercus Group Quercus/ Lobatae; I-J: Quercus aff. Group

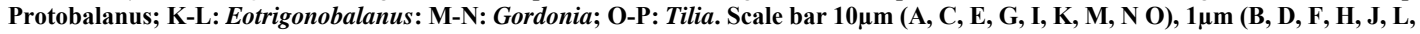

P).

\begin{tabular}{ccccc} 
Sequence & $\mathrm{MAT}\left[{ }^{\circ} \mathrm{C}\right]$ & $\mathrm{CMMT}\left[{ }^{\circ} \mathrm{C}\right]$ & WMMT $\left[{ }^{\circ} \mathrm{C}\right]$ & $\mathrm{MAP}[\mathrm{mm}]$ \\
\hline O3 & $14.0( \pm 4.1)$ & $4.1( \pm 5.1)$ & $23.9( \pm 3.0)$ & $1312.2( \pm 293.9)$ \\
O6 & $15.0( \pm 3.6)$ & $5.5( \pm 5.2)$ & $24.5( \pm 2.4)$ & $1332.6( \pm 278.8)$ \\
m6 & $13.8( \pm 4.8)$ & $4.4 .( \pm 6.0)$ & $23.5( \pm 3.6)$ & $1297.4( \pm 324.2)$ \\
m5.8 & $15.4( \pm 2.5)$ & $6.1( \pm 4.0)$ & $24.8( \pm 1.9)$ & $1359.9( \pm 270.1)$
\end{tabular}

Table1. Summary of average climatic values and average errors of estimated values for each analysed sequence from the middle and late Oligocene and early Miocene (Sequence m5.8 compromise only one analysed sample). 